\title{
Governo dos escravos na mina de Morro Velho
}

\author{
1835-1888*
}

\section{Government of slaves in Morro Velho mine 1835-1888}

\author{
Alisson eugênio** \\ Departamento de Ciências Humanas \\ Universidade Federal de Alfenas \\ Alfenas (MG) \\ Brasil
}

RESUMO Este texto objetiva analisar a administração da população escrava na mina de Morro Velho, para saber se o novo ideário de governo dos escravos, que vinha sendo proposto por intelectuais de diversos campos de saber desde o fim do século XVIII dos dois lados do Atlântico, foi ou não colocado em prática pelos administradores de tal mina e qual resultado disso para as condições de vida e saúde da sua população escrava.

Palavras-chave condições de vida, saúde, demografia.

ABSTRACT This text aims to analyze the administration of slave population in the Morro Velho mine, to see if the new ideas of government of slaves, which had been proposed by intellectuals from various fields of knowledge since the late eighteenth century the two sides of the Atlantic, was put into

* Artigo recebido em: 27/03/2013. Aprovado em: 17/08/2013.

**Contato: alissoneugenio@yahoo.com.br 
practice or not by administrators of such mine and what a result for life conditions and health their slave population.

Keywords life conditions, health, demography

O capital inglês influenciou fortemente a economia brasileira ao longo do século XIX. Os seus agentes souberam aproveitar as oportunidades abertas para sua reprodução quando o Rio de Janeiro passou a sediar a nova capital do império português, estabelecendo acordos e tratados que Ihes permitiram atuar vantajosamente em diversos setores da cadeia produtiva nacional. Um deles foi a mineração. Era exatamente esse setor que, na incipiente e modesta indústria nacional, mais se destacava no século $X I X,{ }^{1}$ sendo a província de Minas Gerais a região geologicamente com maior potencial de exploração de riquezas minerais. Em um dos seus povoados, que viria a ser denominado em 1836 Freguesia de Nossa Senhora do Pilar de Congonhas do Sabará, atual município de Nova Lima (região metropolitana de Belo Horizonte), os ingleses se estabeleceram em 1834 para explorar uma das maiores minas de ouro do mundo: a mina do Morro Velho.

Essa mina foi explorada desde o inicio do século XVIII, após o bandeirante Domingos Rodrigues de Fonseca Lima, em 1701, ter descoberto ouro nos riachos dos Cristais e Cardoso, afluentes do Rio das Velhas. Até 1830, ela pertenceu à família Freitas. O último membro dessa família a explorá-la foi o padre Antônio de Freitas, que a vendeu para o capitão George Francis Lyon, superintendente da mina de Congo Soco, situada em Caeté, pertencente à Saint John del Rey Mining Company Limited. Quatro anos depois, em 1834, este a revendeu para tal empresa, que já operava em São João Del Rey desde os anos $1820 .^{2}$ Aos poucos, ela foi sendo aprimorada graças ao avanço tecnológico industrial que os ingleses notavelmente empreenderam ao longo do século XIX, ao volume de capital investido para viabilizar a eXtração de ouro, ao pessoal técnico e administrativo deslocado da Inglaterra para atuar num novo negócio e à capacidade da empresa de reunir, treinar e governar grande quantidade de força de trabalho para ser empregada, a maior parte, nas galerias do subsolo diretamente na extração de ouro.

Apesar de a política internacional britânica empenhar-se contra a escravidão e o tráfico de africanos desde pelo menos o final da primeira década do século XIX, sob os auspícios do lluminismo, ${ }^{3}$ suas companhias usavam

IBGE. Séries Estatísticas, v.3. Rio de Janeiro: IBGE, 1986, p.343.

MELO, Ciro Flávio de Castro Bandeira de. Nova Lima ontem e hoje. Belo Horizonte: Editora c/Arte, 2008, p.46

3 A esse respeito, é muito esclarecedora a pesquisa de ALEXANDRE, Valentin. O Império Luso-brasileiro em face do abolicionismo inglês. In: SILVIA, Maria Beatriz Nizza da. Colonização e escravidão. Rio de Janeiro: Nova Fronteira, 
mão-de-obra escrava em países em cujas relações sociais predominavam formas arcaicas de exploração do trabalho, como no Brasil, onde as elites reafirmaram no "pacto" constitucional de 1824 a escravidão negra.

Essa foi a justificativa dos diretores da empresa para a utilização de trabalho escravo na mina de Morro Velho, conforme afirmou em relatório de 1849: "Essa é a forma de trabalho do país; os ingleses, ao irem para o mundo à procura de oportunidades, devem por necessidade se conformar com as condições sociais que encontram estabelecidas em cada país". ${ }^{4}$

A empresa tinha alternativa? Teoricamente sim. Poderia ter trazido operários ingleses. Mas o custo da sua mão-de-obra foi considerado demasiadamente oneroso pelos seus proprietários para os padrões de um negócio estabelecido no Brasil. Além disso, a sua organização como classe e suas lutas por melhores condições de trabalho e aumento salarial estavam transformando as ruas das principais cidades industriais inglesas em palco de guerra, o que era muito preocupante na perspectiva patronal.

Poderia ter se empenhado para incentivar homens livres pobres nativos, com atrativos que talvez os motivassem a "vender" sua mão de obra para a companhia, quebrando a sua resistência ao trabalho regular. Afinal, como mostrou Maria Sylvia de Carvalho Franco, eles tinham seu imaginário do trabalho marcado pela degradação, determinada pela escravidão e, com efeito, "alimentavam um projeto de senhores". ${ }^{5}$ Por essa razão, quando a Saint John se estabeleceu na antiga Freguesia de Nossa Senhora do Pilar nos idos do ano de 1834, não havia no Brasil um mercado de mão de obra assalariado amplo e plenamente constituído. E, além disso, grande parte dos indivíduos que se dispunham a trabalhar, principalmente nas localidades cujas economias estavam voltadas para a produção de alimentos para o mercado interno, como aquela freguesia, tinha outras opções para garantir a sua subsistência. A esse respeito, Douglas Cole Libby observou que a superintendência da mina de Morro Velho reclamava recorrentemente das faltas dos seus operários livres. Faltas que ocorriam normalmente nas épocas de plantio e colheita, pois de um modo geral eles pertenciam a famílias de pequenos proprietários rurais tradicionalmente empenhadas na produção agrícola de subsistência e para o abastecimento local, levando à seguinte conclusão: "os trabalhadores livres de Morro Velho ainda não são operários em termos modernos, pois não são totalmente destituídos dos seus meios de produção, em particular a terra". ${ }^{6}$ E como não conseguiam viver apenas dela, vendiam parte de seu tempo para a empresa como forma de complementar a renda familiar, e dessa maneira "não preenchendo totalmente os

1999, p.395-415

4 Annual report. London: Robert Clay, 1849, p.10

5 FRANCO, Maria Sylvia de Carvalho. Homens livres na ordem escravocrata. 4 ed. São Paulo: Unesp, 1997, p.216.

6 LIBBY, Douglas Cole. Trabalho escravo na mina de Morro Velho. Belo Horizonte:Universidade Federal de Minas Gerais, 1979, p.109 (Ciência Política, Dissertação de mestrado). 
requisitos da rigorosa organização do trabalho da companhia". ${ }^{7}$ Assim, sem incentivo além do salário, dificilmente os gestores da mina conseguiriam atraí-los e, principalmente, transformá-los em trabalhadores industriais.

Esses foram os motivos alegados pela Saint John para a utilização de mão-de-obra escrava em suas minas brasileiras, particularmente na de Morro Velho, a maior e mais rentável delas. Para se ter uma idéia da sua dependência dessa forma de trabalho na época, em 1863 a população escrava nela ocupada havia atingido a marca de 1691 indivíduos, compondo 65\% do contingente de seus operários, depois de ter atingido 85\% no período de 1839 a 1847, mantendo-se maior que o percentual médio anual de mão-deobra assalariada até 1879, quando começou a declinar rapidamente até o percentual de $18 \%$ em $1884 .{ }^{8}$ Em outros termos, a empresa preferiu sofrer as pressões do aguerrido abolicionismo de seu país, a enfrentar o desafio de atrair trabalhadores ingleses e de converter os homens nacionais pobres em operários. E isso por razões óbvias do ponto vista capitalista: era mais fácil e barato se adaptar "ao sistema do país", com farta e disciplinada força de trabalho. Sendo assim, resta saber se ao menos o tratamento recebido pelos escravos em sua mina estava afinado com as propostas de governo dos escravos, formuladas por letrados dos dois lados do Atlântico e por grandes proprietários rurais nas Américas, sintonizadas com a llustração e com o ideário reformista e o discurso humanístico de seus expoentes.

Para tanto, é necessário saber se os índices de mortalidade da população escrava na referida mineradora eram menores ou maiores em relação aos mesmos índices vigentes no país e como eram as suas condições de vida, saúde e trabalho comparativamente com demais empreendimentos escravistas de grande porte.

O trabalho pioneiro de Douglas Cole Libby, escrito em 1979, dedicado ao estudo da mina de Morro Velho, com destaque para a análise da mãode-obra nela empregada, objeto do seu quarto capítulo, será muito útil para condução desta investigação. Pois em um dos seus subcapítulos, ele dedica onze páginas (136-147) bastante esclarecedoras sobre a vida no cativeiro da companhia. A partir do seu estudo e da documentação relativa a esse assunto, será possível saber se os proprietários e administradores da mina decidiram ou não colocar em prática o ideário ilustrado sobre o governo dos escravos e qual resultado dessa decisão para as condições de vida e saúde da população escrava.

Esse tema tem sido estudado há algum tempo. No Brasil há dois livros a esse respeito. Um deles é o de Ronaldo Vainfas, publicado em 1986, dedicado ao período colonial brasileiro e baseado nos escritos jesuítas. 0

7 LIBBY, Douglas Cole. Trabalho escravo na mina de Morro Velho, p.154.

8 LIBBY, Douglas Cole. Trabalho escravo na mina de Morro Velho, p.91-94. Os números excluem a força de trabalho europeia. 
outro é o de Rafael de Bivar Marquese, publicado em 2004, focado entre os anos de 1660 e 1860, nas principais áreas produtoras das Américas e sustentado em escritos jesuíticos, tratados médicos e tratados agronômicos. ${ }^{9}$ Esse último autor, o único que enfocou o assunto no período aqui recortado, concentrou sua análise em documentação que se reporta exclusivamente à realidade das grandes fazendas. Então, uma análise sobre o governo dos escravos em um empreendimento minerador organizado aos moldes do trabalho fabril inglês da época da Segunda Revolução Industrial e situado em uma província fortemente urbanizada para os padrões da época, pode, comparativamente, ampliar a compreensão histórica sobre a escravidão em um contexto em que essa forma de organização da produção estava sendo cada vez mais criticada.

Na documentação destacam-se os relatórios anuais da superintendência da mina de Morro Velho, sobretudo a parte elaborada com base nos relatos dos médicos, que cuidavam dos enfermos no hospital da companhia. Esse documento era enviado para a direção da empresa na sua sede em Londres, como forma de prestação de contas das atividades da mina, e nele podem ser encontradas abundantes informações sobre o trabalho escravo, horas de trabalho, rotina, vida cotidiana fora da mineradora, diversões, doenças e todo o esforço para administrar os escravos, conformá-los à sua condição, incentivá-los ao trabalho, ao matrimônio e à moral religiosa. Enfim, ele permite observar o governo dos escravos em Morro Velho. ${ }^{10}$

Há também uma narrativa elaborada no final da década de 1860 por Richard Francis Burton, diplomata britânico, cônsul de sua majestade Rainha Vitória, resultante de uma longa viagem feita por ele ao interior do Brasil, partindo do Rio de Janeiro até chegar à mina de Morro Velho, onde foi conhecer o bem sucedido negócio de seus compatriotas que, no momento de sua visita, havia atingido o auge da produção para em seguida experimentar uma queda abrupta até 1873. Em relação ao tratamento dado aos escravos ocupados na mina, ele afirma ter ficado impressionado com a qualidade de suas vidas. A comida era farta, o vestuário confortável, moradia salubres, hospital com médico trazido de Londres para cuidar das suas doenças, cuidados especiais com as grávidas, e ainda tinham licença para cultivar suas hortas e tratar de seus porcos e suas galinhas, bem como para se divertirem com suas danças e batuques, nos feriados, domingos e horas de folga. ${ }^{11}$

9 VAINFAS, Ronaldo. Ideologia e escravidão: os letrados e a sociedade escravista no Brasil colonial. Petrópolis: Vozes, 1986. MARQUESE, Rafael de Bivar. Feitores do corpo, missionários da mente: senhores, letrados e o controle dos escravos na América. São Paulo: Companhia das Letras, 2004.

10 Parte dessas fontes (1834-1886) encontra-se no Centro de Estudos Mineiros da FAFICH/UFMG, sob a direção de Douglas Cole Libby. Na íntegra (1834-1958), ele encontra-se na Universidade do Texas (EUA).

11 BURTON, Richard Francis. Viagem do Rio de Janeiro a Morro Velho. Brasília: Senado Federal, 2001, p.292 e p.334-336. 
Teria sido assim mesmo a vida dos negros submetidos ao cativeiro na companhia, ao menos quando tal viajante visitou, durante aproximadamente um mês, as suas instalações? Os relatórios dos administradores da mina e a narrativa de Richard Burton não poderiam ter superestimado a realidade? Confrontando os discursos de tais fontes com os dados das estatísticas do hospital da mina, como será feito ao final deste artigo, será possível construir uma ideia do que se passou com a população escrava na mina de morro velho.

Quase duas décadas anteriores à sua visita, artigos estavam sendo publicados em periódicos ingleses denunciando as condições de vida e trabalho dos escravos na mina de Morro Velho. Entre os autores dessas publicações estavam dois de seus ex-funcionários, um médico e um oficial do departamento de redução (britagem, esmagamento e pilagem das rochas). A repercussão de seus testemunhos foi tamanha que a direção da Saint John enviou um investigador de Londres para averiguar a situação, o Dr. Thomas Walker (médico de formação, com experiência no exército britânico). ${ }^{12}$

Naquele momento, o movimento abolicionista inglês estava no auge. Seus integrantes haviam conseguido pressionar o Estado inglês a abolir a escravidão (1834) depois da proibição do tráfico de africanos (1807) para suas colônias. ${ }^{13}$ Possivelmente foi esse o fator decisivo que provocou 0 efeito nos leitores da revista Mining Journal e nos jornais The Observer e Morning Post, que publicaram as denúncias. Já era demais para os críticos da escravidão na Inglaterra tolerar que companhias inglesas submetessem pessoas a essa forma de exploração do trabalho, cada vez mais considerada moral, política e filosoficamente injusta, por ser degradante e contrária aos anseios de progresso e ideais civilizatórios da humanidade. Ainda mais se essa submissão também implicasse em mau tratamento, o que extrapolava o inaceitável para uma mentalidade forjada sob o impacto das sensibilidades produzidas durante as Luzes. Nada mais seria contraditório para uma nação que, naquele contexto histórico, se apresentava como a vanguarda da civilização, agente principal da evolução tecnológica e missionária das mais refinadas virtudes.

Thomas Walker passou algum tempo nas dependências da mineradora britânica instalada na Freguesia de Nossa Senhora do Pilar de Congonhas do Sabará. Visitou a mina, averiguou os seus diversos departamentos, observou os escravos em suas diversas funções, verificou os serviços hospitalares a eles prestados, a sua alimentação, o seu vestuário, a sua habitação, a sua vida fora da empresa, as suas diversões, as suas comodidades etc.

12 LIBBY, Douglas Cole. Trabalho escravo na mina de Morro Velho, p.137, nota 190. A informação sobre a formação de Walker é fornecida por BURTON, Richard. Viagem do Rio de Janeiro a Morro Velho, p.295.

13 KLEIN, Hebert S. O tráfico de escravos no Atlântico. Ribeirão Preto: FUNPEC, 2004, p.194-197. 
Dessa visita, resultou um longo relatório entregue à direção da Saint John em 1851 e a resposta dada pelo seu redator foi a mais positiva possível. Os súditos ingleses, alarmados com o material divulgado na imprensa britânica, agora podiam aquietar suas consciências? Afinal, se a escravidão, na perspectiva da empresa, ainda era necessária nos rincões do mundo, na periferia das sociedades declaradas civilizadas, ao menos os indivíduos que tiveram a infelicidade de suportar os seus grilhões viveram dignamente, em comparação com os padrões de um operário inglês, conforme ele ponderou em seu relato?

Essa foi sua conclusão que em parte acabou sendo divulgada, junto com fragmentos de pareceres de administradores da mina, em uma circular destinada aos proprietários de escravos alugados pela superintendência de Morro Velho. Desde 1843, a sua superintendência estava proibida de comprar negros pela Lei Lord Brougham. Até então ela havia adquirido 412 indivíduos. ${ }^{14} \mathrm{E}$ como estava impossibilitada de novas aquisições, incentivou a reprodução natural e recorreu ao aluguel. Para evitar que os locadores se negassem a alugar seus cativos, preocupados com as notícias dos maus tratos, ela procurou tranquilizá-los com um documento relatando como era a vida dos escravos em sua propriedade. Nele o cirurgião Huger Birt escreveu:

Tive oportunidades incomuns de conhecer a condição dos ingleses pobres nos distritos agrícolas; inclusive, em St. Marylebone tendo tido contato com este último como cirurgião-assistente da Enfermaria Paroquial; além de ser cirurgião por cerca de cinco anos de um distrito de oito paróquias, incluindo um enorme abrigo; e ao comparar suas condições com à dos nossos pretos, a balança pende fortemente a favor de Morro Velho - a maioria deste último possuindo porcos e aves, e ganhando o suficiente para comprar suas pequenas luxúrias; o mais cuidadoso pode, e consegue, em adição a isso, acumular algum dinheiro. Passados alguns dias, fui requisitado por um preto, chamado Honorio Raymondo, para arrumar seu relógio, ao qual estava anexada uma proteção de prata, valendo em conjunto cinco ou seis libras esterlinas, pelo menos; de novo, muitos negros têm vergonha de roupas sucateadas, e compram para si casacos que mecânicos ingleses não precisariam de se envergonhar em vestir. ${ }^{15}$

Esse documento, as respostas do dossiê de Thomas Walker incumbido de investigar as denúncias de maus tratos aos escravos da mina, os relatórios anuais da superintendência, as estatísticas médicas publicadas em anexo nesses relatórios e as impressões do cônsul inglês Richard Burton, quando da sua visita à companhia, serão os testemunhos que darão suporte a esse ensaio.

Para isso, utilizarei como estratégia narrativa a sequência dos relatos daquele investigador, os quais sempre que necessário serão confrontados

14 LIBBY, Douglas Cole. Trabalho escravo na mina de Morro Velho, p.98.

15 Circular to the proprietors. London: Robert Clay, 1851, p.56. 
com as demais fontes. Ele começa seu parecer descrevendo a localização da mina de Morro velho, numa região montanhosa, quente no verão e muito fria no inverno, cortada por rios que percorrem um amplo vale envolvido por densas florestas. Essa informação era de grande importância, porque ainda predominava na medicina a concepção de que o clima constituía um dos principais fatores causadores de doenças. Consequentemente, não ficou surpreso em saber que entre as enfermidades mais comuns na Freguesia de Nossa Senhora do Pilar, as pulmonares tinham considerável incidência, sobretudo nos negros ocupados na companhia. ${ }^{16}$ Pois a maior parte de suas atividades era executada nas entranhas da terra, onde a alta umidade e a excessiva poeira produzida pelas explosões, brocas, picaretas e demais ferramentas típicas da mineração debilitavam seus pulmões.

Mas essa debilidade, comum nos indivíduos dedicados à mineração nas mais diversas experiências observáveis na história, poderia ser atenuada se as suas vidas após as jornadas de trabalho tivessem boas condições. E é exatamente essa a imagem que Thomas Walker procurou construir com o seu dossiê. Pois, após sua descrição dos aspectos morfológicos da localidade onde estava situada a companhia, iniciou uma longa descrição da maneira como os escravos eram tratados em suas dependências. Ao visitar as suas habitações, afirma que nunca viu, no tempo que permaneceu no Brasil, casas de boa qualidade ocupadas pelas "classes baixas", como as construídas pela mineradora para abrigar seus negros. Os casados viviam em casas separadas, os solteiros em alojamentos em grupos de quinze a vinte pessoas, com divisão entre os sexos. Suas residências eram mantidas bem conservadas, arejadas e frequentemente limpas pelos seus ocupantes, pois passavam por vistorias dos feitores e do administrador geral periodicamente. Os locais onde foram erguidos recebiam boa iluminação solar e boa ventilação, com mananciais de água potável, favorecendo a salubridade. ${ }^{17}$

Além de bem abrigados, os escravos também eram bem agasalhados com roupas distintas para o trabalho e as horas de folga, para o verão e o inverno, para os homens e as mulheres. No geral uma blusa de lã, duas camisas de algodão, duas calças, uma touca, um par de luvas, um sobretudo ou camisolão e as mulheres ainda recebiam dois vestidos e um lenço. No auge da estação fria, recebiam um casaco de lã azul como reforço contra as baixas temperaturas, que tornam o vale onde foi erguida a antiga freguesia de Nossa Senhora do Pilar incomodamente gélido. ${ }^{18} \mathrm{O}$ sustento deles podia até mesmo provocar inveja em grande parte da população da época. Eles tinham três refeições por dia: um desjejum, almoço e jantar. A sua dieta básica compunha-se de arroz, feijão, farinha de milho, carne de

16 Annual report. London: Robert Clay, 1851, p.56.

17 Annual report, p.57-58.

18 Annual report, p.58-59; Circular to the proprietors. London: Robert Clay. 1850, p.45. 
vaca ou porco (natural ou seca), café e chá. ${ }^{19}$ Para reforçar seu depoimento, Thomas Walker fez questão de reafirmar que:

Para a boa qualidade geral dos diferentes artigos, e para as boas comidas, posso dar amplo testemunho, tendo ido repetidamente à cozinha e examinando-as, e provando-as e testemunhando a distribuição delas, à qual o feitor comparece para ver se não há irregularidade e para receber quaisquer reclamações, às quais ele deve satisfazer de imediato como pode, e reportar cada uma delas ao gestor dos negros. ${ }^{20}$

Além das refeições fornecidas pela companhia, os seus escravos podiam complementar sua alimentação com o resultado do cultivo de frutas, legumes e verduras, bem como da criação de galinhas e porcos. A superintendência da mina permitia a eles, nas horas e dias de folga, dedicarem-se a essas atividades e até lhes concediam terrenos anexos ou próximos de suas residências para essa finalidade. Inclusive podiam vender o excedente da produção livremente no mercado local, arrecadando o suficiente para ao menos comprarem algumas guloseimas, tabaco ou bebidas espirituosas (aguardente de cana) que podiam tomar, com moderação nos domingos e feriados. ${ }^{21}$

Sobre esse ponto, o consumo de álcool, Thomas Walker ponderou o seguinte:

Aqueles que trabalham numa parte úmida da mina recebem um trago de cachaça, (a bebida típica do país, destilada da cana de açúcar) após deixar o trabalho, apresentando ao feitor em comando um bilhete do dirigente com o qual trabaIharam. Àqueles que também ficam molhados em outro ofício, ocasionalmente Ihes é permitido um trago. Fico inclinado a questionar a política de oferta de tragos realizada dessa forma, não porque um único trago pode trazer mal, mas me parece que tal prática pode, ao induzir os negros a pensarem nisso como positivo, influenciar a encorajar neles essa indulgência nos espíritos à qual já são bastante inclinados. Um copo de café quente e forte seria, creio eu, igualmente benéfico em tal momento, e livre de objeção. Não fiz sugestão alguma neste ponto ao Sr. Keogh, porque fui advertido de que o café estava escasso naquela época. ${ }^{22}$

Havia tempo o álcool era usado, em pequenas porções diárias, como estimulante aos trabalhadores de algumas ocupações. No Brasil, desde os primórdios da Colônia, os que trabalhavam em serviços pesados e em lugares mais frios tomavam um pouco de aguardente (um destilado de cana-de-açúcar). Na mina de Morro Velho, esse costume continuava

19 Annual report, p.60; Circular, p.45; BURTON, Richard Francis. Viagem do Rio de Janeiro a Morro Velho, p.335.

20 Annual report, p.60.

21 Annual report, p.61; Circular, p.45-46

22 Annual report, p.61-62. 
preservado. Tanto que, na Circular aos proprietários de 1850, da relação de provisões básicas dadas aos escravos consta bebida alcoólica, com a ressalva de "quando necessário". ${ }^{23}$

Em seu lugar o delegado da direção da Saint John, em sua missão investigatória, sugeriu café, que é igualmente estimulante, sem provocar os efeitos colaterais do álcool. Tal substituição vinha ocorrendo em todo o Ocidente, onde as forças produtivas avançavam rapidamente, junto com as relações sociais de produção, para o capitalismo moderno. A rigorosa disciplina imposta aos trabalhadores nesse novo sistema chocava-se com um hábito, cada vez mais compreendido na época como "um óbice ao progresso e uma causa de decadência das nações", por provocar nos indivíduos que dele abusam a "ociosidade e a miséria com o seu triste cortejo". ${ }^{24}$

Na sequência de seu relatório, Thomas Walker aborda o universo da produção. A organização das atividades da mina obedecia a uma sistemática divisão de tarefas. Para executá-las, os escravos eram divididos em três classes, conforme suas forças, idade e aptidão. A maior parte atuava no subsolo, ou na linha de frente, abrindo caminho para a abertura de galerias (os foguistas), furando as rochas para encontrar as pedras matrizes que envolviam ouro (broqueiros), selecionando o material apurado para acondicioná-lo nos vagões (selecionadores). Destes até o setor de encaminhamento para a redução, estavam posicionados os negros (carregadores) que recolhiam o material e o colocavam nas caçambas, as quais eram acompanhadas pelos caçambeiros até o setor de pesagem, onde os pesadores faziam o registro do peso do conteúdo transportado, antes dele ser enviado para a redução. Nesse departamento, existiam outras funções que também reuniam grande parte de trabalhadores. Nele reduziam-se as pedras ao máximo possível até a lavagem e a apuração final do ouro. ${ }^{25}$

A carga horária de trabalho, até 1848, era de doze horas diárias para todas as funções. Posteriormente, os escravos destinados às atividades no interior da mina tiveram suas jornadas reduzidas progressivamente até atingir oito horas. Afinal, elas exigiam mais força e atenção deles e lhes expunham a muito mais riscos. Os empregados nas demais especializações tinham horários variados. Um mecânico trabalhava 9 horas e 45 minutos, os da casa de amalgamação 9 horas, os ferreiros 9 horas e 15 minutos. Alguns departamentos funcionavam 24 horas por dia, como o da mina, onde atuavam os empregados da linha de frente da operação de escavação, divididos em 3 turnos. O dia de trabalho começava às seis horas. Quando os sinos soavam 11 horas, havia uma pausa para o almoço de 45 minutos. Até às

23 Circular, p.45.

24 VILHENA, Mathias Antônio Moinho de. Do uso e abuso das bebidas alcoólicas. Rio de Janeiro, 1882, p.60-61 (Tese apresentada à Faculdade de Medicina).

25 Annual report, p.62-66 e Circular, p.42-44. Uma descrição mais detalhada dessas e outras atividades encontra-se em LIBBY, Douglas Cole. Trabalho escravo na mina de Morro Velho, p.123-129. 
17 horas a maioria dos setores da empresa parava, quando era servido o jantar. Essa carga horária, compatível com a vigente no sistema fabril inglês da mesma época, era atenuada com uma pausa de pelo menos 12 horas entre o fim e o início de outra jornada e com uma folga no final de semana. ${ }^{26}$

Após esse período, pelo menos a partir de 1846, os escravos poderiam fazer horas extras remuneradas, com vencimento nada desprezíveis comparados aos padrões salariais e ao custo de vida no Brasil da época. Segundo Douglas Cole Libby, um escravo produtivo poderia acumular até $83 \$ 200$ mil-réis anuais nos idos de 1867, quando a arroba do toucinho $(14,7 \mathrm{Kg})$ custava $6 \$ 645$, o alqueire de feijão (13,8 litros) custava $2 \$ 917$ e um funcionário público empregado como mensageiro dos correios recebia $320 \$ 000$ por ano. ${ }^{27}$

Os que não queriam, ou não aguentavam uma carga adicional de trabalho, iam para suas casas, onde cuidavam das atividades domésticas, hortaliças, roças e criações, ou mesmo nada faziam, a não ser se entregarem a pequenos prazeres da vida, como testemunhou Thomas Walker:

Todos possuem a inteira disposição do seu tempo depois que suas tarefas são terminadas, ou suas horas de labor acabadas, embora não possam ir para além dos limites do estabelecimento sem permissão. Os próprios trabalhadores se encarregam de cuidar de suas aves e porcos, e trabalhar em seus jardins, enquanto outros se deliciam com a indolência letárgica, fumando e desfrutando da sociedade junto com outros igualmente retirados para si no ócio. As mulheres se encarregam de lavar, costurar, e tomar conta das casas e dos filhos. Alguns, tanto homens como mulheres, apanham lenha, e cortam grama, e fazem pequenos trabalhos para ganhar algum dinheiro. ${ }^{28}$

Ao que parece, a criação de porcos era rentável. Na circular destinada aos proprietários de negros alugados para a companhia, o administrador, J. Smyth, informa que os escravos geralmente dedicavam a tarde de sábado aos sacrifícios dos suínos suficientemente gordos para abate. Nas suas pocilgas eram criados aproximadamente duzentos capados, ao custo de dois mil réis em seis meses. Ao final deste período, cada animal podia custar até dezoito mil réis. ${ }^{29}$

O próximo tópico do dossiê daquele delegado da Saint John, encarregado de investigar o tratamento recebido pelos negros na mina de Morro Velho, é a instrução religiosa a que eles eram obrigados. A função da religião no governo dos escravos é claramente expressa no seu dossiê: melhorar a condição deles em relação ao seu comportamento. Havia

26 LIBBY, Douglas Cole. Trabalho escravo na mina de Morro Velho, p.136-7. Annual report, p.62-66; Circular, p.37 e p.42-44.

27 LIBBY, Douglas Cole. Trabalho escravo na mina de Morro Velho, p.105-106.

28 Annual report, p.67.

29 Circular, p.46. 
uma capela anglicana na época, onde um sacerdote todas as manhãs regia algumas preces e aos domingos celebrava um culto. Eles deveriam comparecer às preces logo após o desjejum. Nesse momento faziam uma oração comandada pelo capelão e ouviam algumas rápidas palavras de conteúdo moral, encerrada com a benção para, em seguida, iniciarem suas tarefas. ${ }^{30}$

Mas a vida religiosa dos escravos a serviço da mineradora não se resumia a essas atividades. Em um dos morros da freguesia de Nossa Senhora do Pilar, eles podiam frequentar a irmandade religiosa dedicada à Nossa Senhora do Rosário, mantida pelos negros da localidade desde 1774, quando foi criada, e que até hoje abriga a cultura remanescente dos afrodescendentes na cidade de Nova Lima (originada da referida freguesia). Nas alvoradas dominicais, enquanto os ingleses participavam das celebrações cristãs à moda anglicana em sua capela, os escravos iam para a sua igreja, no morro do Rosário, cultuarem suas devoções, fossem elas católicas, ou africanas, ou mesmo as de forma sincrética.

Ao final da missa, muitos deles dirigiam-se para a venda da freguesia, onde bebiam, comiam, dançavam, brincavam, namoravam, enfim, aproveitavam o resto do dia com divertimentos. ${ }^{31}$ Isso preocupava a direção da empresa, pois, segundo averiguação de Thomas Walker, as suas idas dominicais para o centro comercial da localidade favoreciam "a bebedeira e outras desordens", razão pela qual sugeriu à superintendência da mina a construção de uma capela própria para eles nas dependências da companhia, o que poderia facilitar seu controle. ${ }^{32}$

A propósito, essa parte do relato esclarece o ponto central da visita daquele investigador britânico às dependências da mina de Morro Velho. Caso realmente os escravos fossem excessivamente explorados, com altas jornadas de trabalho e, como se isso não bastasse, recebessem tratamento ruim, mais do que contradizer a imagem que a Inglaterra procurou construir como uma nação espelho da civilização, mais do que aguçar as críticas dos seus cidadãos abolicionistas, o que mais preocupava eram outras coisas. Primeiro o fluxo de escravos alugados à empresa. A circular para os proprietários na verdade foi um conjunto de esclarecimentos destinado a eles após os alarmes provocados pelos abolicionistas ingleses. Segundo, a manutenção da ordem na população escrava. A esse respeito, o agente-chefe da mineração, Thomas Treloar, expressou claramente, em relação ao governo dos escravos (nos seus próprios termos, "governing blacks"), a necessidade fundamental de "inculcar neles valores morais e religiosos", bem como "encorajá-los a amar

30 Annual report, p.68.

31 Circular, p.45.

32 Annual report, p.68. 
e terem prazer ao dinheiro", incentivando-os a cultuarem hortas e animais nas horas de folga do cativeiro. ${ }^{33}$

Uma instituição considerada estratégica nesse quesito é o matrimônio. Os escravos eram incentivados ao casamento, recebendo presentes, casa exclusiva e até recompensas em dinheiro, além das despesas com o ritual, as vestimentas próprias para a ocasião e alianças. ${ }^{34}$ Em junho de 1850 havia 83 casais de cativos casados na companhia, com numerosas crianças, o que foi considerado suficiente para manter a população cativa, na opinião de Thomas Walker. ${ }^{35}$ As crianças, enquanto os pais trabalhavam, tinham um tempo para brincar, outro para receber instrução religiosa e mais outro para aprender um ofício. Abaixo segue uma lista dos garotos e dos ofícios a eles ensinados. ${ }^{36}$

\begin{tabular}{|c|c|c|c|}
\hline Nome & Idade & Sob os cuidados de & Ofício \\
\hline Mariano & 9 & Robert Quick & Carpinteiro \\
\hline Floriano & 7 & W. Bawden & " \\
\hline Delpfino & 8 & Thos. Hancook & “ \\
\hline Joze Delfino & 8 & Simão & $"$ \\
\hline Lorenço & 7 & Josh Gregor & $"$ \\
\hline Gaspar (liberto) & 7 & W. Robson & " \\
\hline Jannario & 10 & Delfino & Pedreiro \\
\hline Fellicio & 12 & Maliphant & " \\
\hline Rodrigo & 12 & Cornelius & “ \\
\hline Valentine & 7 & Jozo Fostino & " \\
\hline Augusto & 10 & Richard Luke & Ferreiro \\
\hline Adão & 7 & Walter Tregellas & " \\
\hline Galdino & 12 & Wm. Warren & $"$ \\
\hline George & 8 & John Seymor & " \\
\hline Henrique & 6 & Thos. Tregellas & $"$ \\
\hline Germano & 8 & James Knight & $"$ \\
\hline Venancio & 6 & John Rose & $"$ \\
\hline João Delfino & 6 & Joze Mario & Mineiro \\
\hline Ignacio & 7 & Mensageiros & $"$ \\
\hline Jozé & 6 & Mensageiros & $"$ \\
\hline Marcellino & 7 & Peões & $"$ \\
\hline
\end{tabular}


Para completar o quadro do controle sobre a população escrava na mina, a administração da companhia promovia festas em alguns feriados, conforme descrição do superintendente Mr. Keogh em carta destinada à direção da companhia em Londres e reproduzida na Circular aos proprietários:

Em minha última carta, prometi dar a você uma descrição da festa para os pretos desse estabelecimento, que ocorreu na Segunda-feira de Páscoa. É um dia Santo para nós todos. Os entretenimentos começaram por volta do meio dia. Eles consistem de todos os jogos atléticos que você pode imaginar. Os vitoriosos - a saber - homens, mulheres e crianças, ganharam prêmios, como vestidos, xales, tocas, lenços, porcos e etc. No fim da tarde, uma grande fogueira foi acendida; foram soltados fogos de artifício e os pretos dançaram suas danças típicas. As pessoas da Casa Grande compareceram com eles todo o tempo, o que trouxe grande entusiasmo à comemoração. Lá havia mais de mil negros reunidos, além de ingleses; e não ocorreu a menor dos tumultos. Não vi nem sequer uma pessoa embriagada, tudo era alegria e bons sentimentos. Desejo que os diligentes possam ter testemunhado essa cena; tanta alegria acontecendo, combinada com tão agradável ordem. ${ }^{37}$

Assim, esperava-se que os escravos se sentissem satisfeitos, ou nas palavras de J. Smyth, administrador da mina, "confortáveis e felizes", pois com todas essas comodidades, suas vidas "eram melhores do que o geral das classes laboriosas na Inglaterra". ${ }^{38}$

O governo dos escravos não estava completo sem as punições aos negros de mau comportamento. Durante sua investigação, Thomas Walker apurou que se praticavam castigos físicos nas dependências de Morro VeIho desde o início das suas operações na freguesia de Nossa Senhora do Pilar, nos idos de 1834, com considerável frequência. Descobriu também que, na opinião dos administradores, tal prática trazia desvantagens ao trabalho, porque os escravos tornavam-se intratáveis, razão pela qual ela foi proibida a partir de 1848, exceto em ocasiões muito extraordinárias (no caso do roubo, por exemplo). Mesmo assim, os feitores foram orientados a confinar os delinquentes em celas ou quartos escuros, ou, até mesmo, prendê-los com correntes nas pernas (no caso dos que recorrentemente saiam das dependências da companhia sem obtenção de licença). Às vezes, recorria-se a palmatórias quando se tratava de caso mais grave de insubordinação, e se a gravidade ocorresse pela terceira vez, vendia-se o insubordinado, ou o devolvia ao seu dono caso fosse alugado. ${ }^{39}$

Todavia, as punições mais aplicadas, principalmente após 1848, estão relacionadas ao cerceamento dos fragmentos de liberdade gozados pelos cativos nas brechas de tempo do cativeiro. Proibiam-lhes a saída para a

39 Circular, p.11; Annual report, p.70-71; LIBBY, Douglas Cole. Trabalho escravo na mina de Morro Velho, p.157-158. 
freguesia, a cultura das hortas, pomares e criação de animais, ou a comercialização dos seus excedentes, Ihes aplicavam multas em dinheiro e os retiram das listas de premiações. ${ }^{40}$

Quase duas décadas após a conclusão do relatório do encarregado pela Saint John de investigar o tratamento dos escravos na mina de Morro Velho, Richard Burton admitiu a eficácia desse novo método de penalizar os infratores, ao afirmar ter notado "a conduta bem educada e respeitosa dos negros", não podendo "haver melhor prova que são bem tratados". No entanto, observou que punições mais severas (confinamento em celas e imobilização das pernas em correntes dos escravos recuperados em fuga) ainda se praticavam na companhia nos casos de má conduta grave, tais como "embriaguez contumaz, desobediência de ordens, insubordinação ou roubar um companheiro". Tais condutas, segundo seu depoimento, pareciam ser exceção, pois "a lista de castigos é baixada quinzenalmente e, em geral, é pequena". ${ }^{41}$

O próximo assunto do parecer de Thomas Walker são os serviços médicos prestados aos escravos. A percepção de que a medicina poderia ser convertida em um instrumento estratégico para as atividades produtivas nas colônias começou a ser formada desde pelo menos as décadas finais do século XVIII, quando uma convergência de fatores (pressões das Luzes, criação da Sociedade pela Abolição do Tráfico, em 1787, na Inglaterra, revolução negra no Haiti, aumento dos preços dos escravos) criou as condições para o tratamento da escravaria ser melhorado. ${ }^{42}$ Nessa mesma época, a saúde da população em geral estava sendo transformada em assunto de interesse público, dado o impacto das doenças na estrutura demográfica e na vida material das sociedades. É a partir desse momento que a assistência médica, aos poucos, foi inserida no rol das obrigações do Estado, ${ }^{43}$ culminando no que se conhece como saúde pública, isto é, conjunto de medidas governamentais para prevenir e combater os problemas de saúde que afetam ou podem afetar o conjunto dos cidadãos de uma comunidade.

Nesse mesmo contexto, no Brasil, a assistência médica começou também a ser aplicada no governo dos escravos, sobretudo após o fim do tráfico de africanos, quando a montagem de enfermarias, hospitais e farmácias e até mesmo a contratação de médicos em grandes estabelecimentos produtivos deixa de ser algo raro de se encontrar na documentação histórica. ${ }^{44}$ Na mina de Morro Velho isso ocorreu em 1838, quatro anos após

40 Annual report, p.70.

41 BURTON, Richard Francis. Viagem do Rio de Janeiro a Morro Velho, p.337.

42 MARQUESE, Rafael de Bivar. Feitores do corpo, missionários da mente, p.103-111. EUGENIO, Alisson. Doenças de escravos com problema médico no final da Era das Luzes. Varia História, n.23, p.154-163, 2000.

43 FOUCAULT, Michel. Microfísica do poder. 13 ed. Rio de Janeiro: Graal, 1998, p.194.

44 Em Cantagalo (Província do Rio de Janeiro), por exemplo, um médico observou que havia hospital em diversas fazendas. TEUSCHER, Reinhold. Algumas considerações sobre a estatística sanitária dos escravos. Rio de Janeiro, 1853, p.6 (Tese apresentada à Faculdade de Medicina). Em outras fazendas o mesmo pode ser observado, como 
o início de suas operações na Freguesia de Nossa Senhora do Pilar. Dez anos depois a companhia inaugurou um novo hospital, com capacidade para 60 leitos, o triplo do anterior, cujas dependências eram tão boas quanto os de Londres, segundo depoimento do seu diretor, por ele ser amplo, arejado, confortável, limpo, dotado de banhos quentes, boa alimentação e, principalmente, acompanhamento médico de qualidade..$^{45}$

No mesmo ano, os relatórios anuais da superintendência, destinados à sede da Saint John, passaram a apresentar estatísticas do hospital, seguidos de considerações do médico responsável por esse setor sobre as condições gerais de saúde dos operários da mina, particularmente dos escravos. Tratase do que Foucault definiu como "a constituição do indivíduo como objeto descritível e analisável (...), que permite a medida dos fenômenos globais, a descrição dos grupos, a caracterização dos fatos coletivos, as estimativas dos indivíduos entre si". Trata-se de "um saber médico administrativo que servia de núcleo original à economia social e a sociologia do século XIX" ${ }^{46}$

Os grandes empreendimentos escravistas, ao integrarem esse saber no cotidiano do cativeiro, buscavam reduzir os índices de mortalidade de seus escravos, sendo a Morro Velho (o maior de todos eles) um dos que o inseriu na sua administração visando completar o quadro dos seus esforços para melhorar as condições de vida, saúde e trabalho dos negros nela empregados. Resta saber se ela atingiu esse objetivo, analisando os dados produzidos pelos seus médicos no seu hospital a partir de 1849 até a última década da escravidão.

Mas antes é necessário conhecer as condições de saúde da população escrava da companhia, segundo a investigação de Thomas Walker, para saber quais problemas mais a afetavam até aquele ano, quando as sistematizações do exercício da medicina na mina começaram a elaborar seus registros estatísticos.

A maior parte do parecer daquele investigador, 13 das 36 páginas, é dedicada aos problemas de saúde da população escrava. Logo ao chegar à Morro Velho, espantou-se com o grande número de mortes ocorridas entre 1848 e 1849 entre seus operários, particularmente escravos vitimados por enfermidades do aparelho respiratório. Ao investigar as causas disso, descobriu ter havido na Freguesia de Nossa Senhora do Pilar uma epidemia de gripe (influenza) que se alastrou até a companhia. Doenças do mesmo gênero (bronquite, pneumonia e pleurisia) revelaram-se disparadamente em

mostram os estudos de: BARBOSA, Keith Valéria de Oliveira. Doença e cativeiro: um estudo sobre mortalidade e sociabilidade escravas no Rio de Janeiro. Rio de Janeiro: Universidade Federal Rural do Rio de Janeiro, 2010 (História, Dissertação de mestrado); MARIOSA, Rosilene Maria. O tratamento e doenças de escravos na Fazenda de Santo Antônio do Paiol 1850-1888. Vassouras: Universidade Severiano Sombra, 2006 (História, Dissertação de mestrado).

45 Circular, p.19-20 e p.22; LIBBY, Douglas Cole. Trabalho escravo na mina de Morro Velho, p.140.

46 FOUCAULT, Michel. Vigiar e punir. 19 ed. Petrópolis: Vozes, 1999, p.157-158; FOUCAULT, Michel. Microfísica do poder. 13 ed. Rio de Janeiro: Graal, 1998, p.202 
relação às demais (diarreia, enterites, contusões, reumatismo etc.), exceto as que estavam ligadas a acidentes de trabalho (as que mais ocupavam o primeiro lugar nas estatísticas produzidas no hospital da mina), as que mais afetavam a população escrava. Elas eram muito comuns na Freguesia de Nossa Senhora do Pilar, onde o inverno é bastante rigoroso. Ao comparar a incidência delas na localidade e nos trabalhadores da mina, observou que nessa última havia maior proporção de afetados, devido à natureza do trabalho na mineração, mas menor proporção de mortes, devido à assistência médica de qualidade e medidas preventivas (alimentação saudável, roupa adequada, moradia confortável e trabalho moderado). ${ }^{47}$

Ao visitar outras minas da mesma companhia e companhias diferentes, ele concluiu que mineiros e demais trabalhadores do subsolo, "underground labourers", são mais susceptíveis àquelas moléstias, razão pela qual, em sua opinião, não se podia atribuir a sua grande ocorrência na Morro Velho a uma situação particular dessa mineradora. Pois, conforme ele considerou, seus escravos recebiam bom tratamento, diferentemente do que ocorria em muitas propriedades, como em uma no arraial de Santa Rita, próxima da localidade em foco, onde apurou que os cativos recebiam pouca comida, viviam mal agasalhados e trabalhavam muito, inclusive domingos e feriados. ${ }^{48}$

Por essa razão, Thomas Walker concluiu seu relatório, em relação ao governo dos escravos, favoravelmente com as seguintes palavras: "O resultado das minhas investigações, sobre as acusações do cruel e assassino tratamento recebido pelos negros, imputadas ao Sr. Keogh e aos diretores, é o contrário, pois as condições deles têm sido em diversos aspectos melhorada". ${ }^{49}$

Enquanto as suas conclusões estavam sendo entregues aos diretores da Saint John em Londres, a superintendência de Morro Velho elaborou uma circular para os proprietários dos escravos a ela alugados, a fim de motivá-los a manterem o interesse por novos contratos com a empresa.

Para tanto, procuraram reiterar, com fragmentos de depoimentos do seu diretor geral, que era "humano e generoso o tratamento dos negros", como "a humanidade sugere", de maneira a "melhorar sua condição na escala humanitária". ${ }^{50}$ Isso quer dizer que, além de dar satisfação à sociedade britânica, particularmente ao movimento abolicionista, fazia-se necessário dar explicações aos escravagistas locais, pois o funcionamento da mineradora dependia muito deles, já que ela estava proibida por lei inglesa (1843) de comprar negros.

47 Annual report, p.74-75.

48 Annual report, p.76 (generalidade da doença) e p.83-84 (situação dos escravos em outras propriedades).

49 Annual report, p.85-86.

50 Annual report, 1855, p.58-59. LIBBY, Douglas Cole. Trabalho escravo na mina de Morro Velho, p.101-103. 
Essa dependência acabou sendo maior a partir de 1850, quando ocorreu a extinção definitiva do tráfico de africanos no Brasil, pois houve em alguns anos depois uma certa crise de abastecimento desse tipo de mãode-obra, muita mais drástica nos municípios desconectados da agroexportação cafeeira, que resultou no encarecimento dos preços dos escravos. No relatório anual de 1852, por exemplo, tentava-se atrair trabalhadores livres para a mina, sem êxito (dado o fato de que os indivíduos que poderiam se empregar na mina tinham de um modo geral horror ao trabalho regular e altamente disciplinado como exige o capitalismo industrial): "Nosso hospital e os nossos recursos estão muito próximo ou igual a qualquer um em Londres. A comida, as roupas e apetrechos dos negros ultrapassam de longe qualquer um da mesma classe em qualquer lugar que eu tenha visto". ${ }^{1}$

Alguns anos depois, em 1855, a situação parecia piorar. No relatório do mesmo ano, o superintendente explicava à direção londrina que os cafeicultores estavam concentrando seus esforços para comprar escravos no mercado interno, após a extinção do tráfico, fazendo elevar demais os preços de mão-de-obra compulsória. Tanto que o valor do aluguel de um escravo de "primeira classe" saltou de $100 \$ 000$ nos anos 1840 para 250\$000 nos anos 1850.

Assim era fundamental para a companhia construir, perante os locadores de escravos, uma imagem compatível com os atributos que faziam da Inglaterra uma das principais protagonistas do progresso das civilizações na "Era dos Impérios", para não ter suas operações inviabilizadas, por falta de homens que pudessem satisfazer a voracidade do trabalho demandado pela sua mina, até encontrar outra opção.

Diante desses relatos, pode-se concluir que seu governo de escravos expressa o idealismo humanitário das Luzes, sendo conduzido com os mesmos fundamentos postulados nos escritos sobre o manejo da população escrava em grandes propriedades. No entanto, apresenta algumas diferenças de conteúdo. Por exemplo, o pagamento de horas extras aos negros, o incentivo à comercialização dos excedentes de sua produção de animais, frutas e hortaliças e o "amor ao dinheiro" para encorajá-los a assimilar o espírito da indústria, conforme ponderou o diretor da administração de Morro Velho, John Routh, em 1850.52

Inclusive, depois de justificar em algumas passagens da Circular o trabalho escravo como um mal necessário, em um país onde os homens livres e pobres ainda não haviam sido convertidos à ideologia do trabalho sustentada pelo liberalismo, dada a sua longa tradição da escravidão, a

51 Annual report, 1852, p.55. Diversos municípios mineiros afirmaram no inquérito agrícola de 1858 que seus proprietários ressentiam-se de falta de braços. EUGÊNIO, Alisson. Inflação, subsistência e carestia em Minas Gerais em meados do século XIX. História e Economia, v.9, n.2, p.83-95, 2011

52 Circular, p.52. 
direção da mina enfatizou a sua posição contrária a essa forma de organização de produção:

\begin{abstract}
Os diretores têm esperança de que vai chegar o tempo em que uma mudança na condição social do Brasil, a esse respeito, venha a ocorrer. Eles estão preparados para fazer tudo em seu alcance, por meio de medidas prudentes e criteriosas, para acelerar isso, sem que se crie alarde ou hostilidade nas mentes do Governo do país no qual trabalham. Agindo, assim, sob uma consciente impressão da responsabilidade que deles decorre - com uma percepção profunda de todos os males da escravidão - dando tudo de si, na prática, para remover esses males, ao menos no que refere aos negros da Cia. ${ }^{53}$
\end{abstract}

Entretanto, se os escravos dessa mineradora tivessem deixado algum testemunho do tratamento nela recebido, eles diriam que eram felizes, como diversas vezes a superintendência da empresa afirmou na Circular para os proprietários? ${ }^{54}$

Não podemos ouvi-los, mas nos registros e estatísticas produzidos pela burocracia da companhia dados podem ser confrontados em busca de alguns indicadores sobre a saúde da população escrava, para saber se eles reforçam ou contradizem o parecer de Thomas Walker, as considerações da Circular aos proprietários e as narrativas dos relatórios anuais da superintendência.

Desde o Annual report de 1848, os médicos da mineradora apresentavam anualmente quadros estatísticos do tratamento de doentes no seu hospital (Tabelas 1 e 2 em anexo). Considerando até o ano de 1885, o maior número de atendimentos ocorreu em 1853, com 2370, e o menor ocorreu em 1881, com 847. A quantidade de doenças oscilou entre 52 (em 1857) e 93 (em 1866). Os problemas de saúde mais recorrentes foram: $1^{\circ}$ ) acidentes (contusões, ferimentos e fraturas), $2^{\circ}$ ) enterites (inflamações gástrica e intestinal), $3^{\circ}$ ) diarreia, $4^{\circ}$ ) disenteria e $5^{\circ}$ ) bronquite. Possivelmente os acidentes devem ter sido a maior causa de óbitos na companhia. A estatística hospitalar somente apresenta 37 mortes ocorridas nas suas dependências. As ocorridas durante o trabalho não estão clara e rigorosamente computadas em seus registros. Em alguns anos, os relatórios anuais apresentam os números dos acidentes fatais. Em outros não, ou apenas se afirma "morreu na mina" sem especificar se foi de acidente, ou foi "de repente", como às vezes acontecia. Para se ter uma ideia dessas cifras, entre os anos $1850 \mathrm{e}$ 1870 foram registrados pelo menos 60 acidentes fatais nos relatórios anuais da superintendência, ${ }^{55}$ e em 1886 ocorreu o desastre considerado mais

53 Circular, p.53

54 Circular, p.21-22

55 Usando outro método para estimar o número de acidentes fatais, comparando o percentual de óbitos geral da população escrava com o percentual de óbitos incluindo os acidentes fatais, o aumento da taxa de mortalidade varia de 0,24 a 1,1 entre 1865 e 1868. No ano de 1867, por exemplo, ocorram 26 mortes em um único acidente; 
terrível de todos até então, quando aproximadamente 600 trabalhadores foram fatalmente soterrados. ${ }^{56}$

Todos esses números, colididos com os relatórios médicos, dizem que os traumas e ferimentos causados por acidentes de trabalho, as doenças do sistema respiratório e as do sistema digestivo eram os problemas de saúde mais tratados pelos médicos da companhia. Comparando-os com dados de outras realidades de diferentes épocas, chega-se à mesma conclusão. ${ }^{57}$ É bom lembrar que nem todos os pacientes do hospital de Morro Velho eram escravos, mas a maioria até $1878 \mathrm{sim}$. Em 1872, por exemplo, o médico responsável pelo relatório da estatística hospitalar, Alex Buchanan, ao considerar muito alta a frequência de atendimento (1973 ao todo somente naquele ano), disse que "a maior parte dos casos ocorreu entre indivíduos negros, fracos de constituição e predispostos a adoecer". ${ }^{58}$

Não foi possível comparar o percentual de mortes entre os escravos e os operários assalariados da mineradora, porque para esses últimos seus registros apenas apresentam dados esparsos. Para os outros (ver anexo), as cifras são apresentadas desde o começo das operações na Freguesia de Nossa Senhora do Pilar. Nos anos iniciais, somente entre os escravos de propriedade de Morro Velho, os índices de óbitos chegaram a atingir o marco de 7,9\% (30 mortes em 378 adultos) em 1840, segundo o pioneiro estudo de Douglas Cole Libby. ${ }^{59}$ Do ano seguinte, incluindo os escravos alugados, quando a taxa reduziu-se para $6,1 \%$, o percentual oscilou até declinar para $2,1 \%$, subindo novamente até encontrar o pico de 6,15\% em 1853, variando posteriormente até cair para 1,45\% em 1884 (Tabela 3 e Gráfico 2).

Comparando essas taxas com as de população escrava no país, na mesma época, por exemplo, na Santa Casa de Misericórdia do Rio de Janeiro entre 1840 e 1851, onde elas oscilavam entre 2,74\% e 4,9\%, na média elas são compatíveis. Quando confrontados com o mesmo segmento populacional de meio século atrás, Vila Rica, entre 1799 e 1801, onde a média era de $20 \%,{ }^{60}$ observa-se expressivo decréscimo, possivelmente derivado

Annual report, 1868, p.83-84. Sobre as principais causas de acidentes em minas e a gravidade deles, sugiro as páginas 214 a 298 do capítulo 4, O ouro gosta de sangue, de SOUZA, Rafael de Freitas. Trabalho e cotidiano na mineração aurifera inglesa em Minas Gerais: a Mina de Passagem de Mariana. São Paulo: Universidade de São Paulo, 2009 (História, Tese de doutorado).

56 LIBBY, Douglas Cole. Trabalho escravo e capital estrangeiro no Brasil: o caso da Morro Velho. Belo Horizonte: Itatiaia, 1984, p.62-65.

57 Vários testemunhos e autores comprovam essa conclusão. O cirurgião Luís Gomes Ferreira: Erário Mineral (1735). Belo Horizonte: Fundação João Pinheiro, 2002, p.229 e p.239. O médico Reinhold Tuesher: Algumas observações sobre a estatística sanitária dos escravos nas fazendas de café. Rio de Janeiro, 1853, p.9-11 (Tese apresentada à Faculdade de Medicina). KARASH, Mary. A vida dos escravos no Rio de Janeiro. São Paulo: Companhia das Letras, 2000, p.497. KENNETH, Kiple F. The caribbean slavery: a biological history. Cambridge: Cambridge University Press, 1984, p.140-144.

58 Annual report, 1872, p.87

59 LIBBY, Douglas Cole. Trabalho escravo e capital estrangeiro no Brasil, p.62-64.

60 KARASH, A vida dos escravos no Rio de Janeiro, p.165. LUNA, Francisco Vidal et al. Escravismo em São Paulo e Minas Gerais. São Paulo: Edusp, 2009, p.243. 
da melhoria do tratamento dos escravos, principalmente com a introdução do saber médico e da montagem de um hospital na empresa.

Ao analisar os dados relativos às crianças, entre 1848 e 1868 (a partir dessa data faltam dados de óbitos), excluindo os anos de 1849, 1850 e 1852 (porque faltam dados de nascimento para o primeiro ano e dados de óbitos para os demais anos) houve um saldo demográfico positivo de 69 (129 nascimentos contra 60 mortes) entre os escravos da companhia. Em relação aos escravos alugados, excluindo o ano de 1849 (porque não houve registro de nascimento naquele ano) o saldo no mesmo período é de 421 (545 nascimentos e 124 óbitos), totalizando 490 (Tabela 4 e Gráfico 5). ${ }^{61}$

Confrontados com os cálculos de Mary Karasch para o Rio de Janeiro entre 1840-1851 e Iraci Del Nero da Costa para Vila Rica entre 1799 e 1801, onde o obituário infantil excedia os nascimentos, verifica-se que na mina de Morro Velho as crianças tinham maior chance de sobrevivência, mas não o suficiente para aumentar naturalmente a população escrava. Pois, nela, entre 1848 e 1868, houve mais mortes dos adultos do que crianças sobreviventes, como se vê na Tabela 5 em anexo.

Tomando os dados da referida tabela, excluindo o ano de 1847, porque somente encontrei os dados em percentuais até aquele ano para mortes dos adultos, e os anos 1849, 1850 e 1852 (porque não foi possível calcular o saldo demográfico das crianças naqueles anos), têm-se os seguintes resultados: 1) em relação aos escravos da companhia, 121 mortes de adultos e 59 de saldo positivo - nascimento menos mortes - entre as crianças, provocando decréscimo populacional de 62 indivíduos; 2) em relação aos escravos alugados pela companhia, excluindo os mesmos anos pela mesma razão, 876 mortes de adultos e 427 de saldo positivo - nascimentos menos mortes - entre as crianças, provocando um decréscimo populacional de 449 indivíduos. Somando toda a escravaria, 948 mortes de adultos e 486 de saldo positivo - nascimento menos mortes - entre as crianças, há uma perda demográfica de 462 indivíduos.

Assim as estatísticas hospitalares de Morro Velho revelam que a população escrava estava em franco declínio (mesmo sem contar as taxas de alforrias na empresa, difícil de calcular nos relatórios), apesar da queda da mortalidade dos adultos (Tabela 3 e Gráfico 2) e do aumento médio do saldo demográfico positivo das crianças (Tabela 4 e Gráfico 5). E isso porque o número de mortes dos adultos prevaleceu em quase todos os anos sobre os nascimentos, como a Tabela 5 revela (somente ocorreram mais nascimentos de crianças do que mortes de escravos da companhia em 1851, 1857, 1858 e 1861, e no caso dos alugados o mesmo apenas ocorreu em 1855 e 1858).

61 Não foi possível calcular até 1888, porque a partir de 1870 a empresa parou de registrar óbitos de crianças. 
Esses dados mostram que, após o fim do tráfico de negros africanos em 1850 e as investigações de Thomas Walker, sobre as denúncias de maltratos aos escravos na mina de Morro Velho, concluídas no mesmo ano, houve esforço por parte dos proprietários e da administração da mina para melhorar as condições de vida e saúde em suas dependências. Mostram também que tal esforço gerou queda dos percentuais de mortalidade da população escrava em geral (Gráfico 2), inclusive das crianças (Gráfico 4) entre as quais em todos os anos praticamente houve saldo positivo dos nascimentos em relação aos óbitos (Tabela 4). E isso, em grande parte, graças à introdução do saber médico (construção de enfermarias, uso de manuais de medicina prática, contratação de médicos e enfermeiros e vacinação), de uma nova política de punições, de redução das jornadas de trabalho, de melhora na alimentação e vestuário, de estímulo ao casamento e de incentivo à produção de alimentos para comercialização nas horas de folga, conforme o ideal de administração de grandes propriedades escravistas divulgado por autores que, desde as últimas décadas do século $\mathrm{XVIII}$, vinham escrevendo sobre o assunto nas principais áreas escravistas das Américas.

No entanto, todo esse esforço não foi suficiente para o aumento demográfico da escravaria na mina de Morro Velho, porque a morte, apesar de sua redução considerável após o fim do tráfico de escravos africanos para o Brasil em 1850, ainda continuava prevalecendo nela. Assim, pode-se dizer que as melhorias no governo dos escravos relatadas pelos administradores da companhia, pelo investigador Thomas Walker e pelo consul "viajante" Richard Burton, se realmente foram tão louváveis como eles tentaram fazer crer, não foram suficientes para que a dinâmica populacional cativa resultasse em uma tendência de aumento natural, como revelam as estatísticas produzidas pela própria mineradora. 


\section{Anexos}

Tabela 1

Escravos internados afetados por doenças pulmonares entre os pacientes do hospital da mina de Morro Velho

\begin{tabular}{|c|c|c|c|c|c|c|c|}
\hline \multicolumn{2}{|c|}{ Internações } & \multicolumn{6}{|c|}{ Doenças pulmonares } \\
\hline Ano & Internados & Bronquite & Pneumonia & Tuberculose & Outros & TOTAL & $\%$ \\
\hline 1847 & 1307 & 30 & 23 & 2 & $444^{\star}$ & 499 & $39 \%$ \\
\hline Mortes & 22 & 2 & 1 & 1 & 6 & 10 & $46 \%$ \\
\hline 1848 & 2335 & 52 & 51 & 1 & $542^{*}$ & 646 & $28 \%$ \\
\hline Mortes & 59 & 5 & 10 & 1 & 10 & 26 & $44 \%$ \\
\hline 1849 & 2333 & 20 & 120 & 2 & 367 & 509 & $22 \%$ \\
\hline Mortes & 84 & 3 & 13 & 2 & 15 & 33 & $40 \%$ \\
\hline 1850 & 1386 & 41 & 54 & - & 321 & 416 & $30 \%$ \\
\hline Mortes & 52 & 6 & 6 & - & 8 & 20 & $39 \%$ \\
\hline 1851 & 1249 & 23 & 80 & 2 & 336 & 441 & $36 \%$ \\
\hline Mortes & 40 & 2 & 6 & 1 & 43 & 52 & $130 \%$ \\
\hline 1852 & 1580 & 30 & 52 & 4 & $250 *$ & 336 & $22 \%$ \\
\hline Mortes & 43 & - & 9 & 3 & - & 12 & $28 \%$ \\
\hline 1853 & 2370 & 55 & 82 & 12 & $415^{\star}$ & 564 & $24 \%$ \\
\hline Mortes & 95 & 1 & 18 & 2 & 2 & 23 & $25 \%$ \\
\hline 1854 & 2178 & 62 & 40 & 29 & $312^{*}$ & 443 & $21 \%$ \\
\hline Mortes & 68 & 1 & 3 & 6 & 3 & 13 & $20 \%$ \\
\hline 1855 & 1839 & 123 & 45 & 2 & 147 & 317 & $18 \%$ \\
\hline Mortes & 32 & 2 & 1 & 1 & 1 & 5 & $16 \%$ \\
\hline 1856 & 1813 & 76 & 76 & 16 & $360^{*}$ & 528 & $30 \%$ \\
\hline Mortes & 54 & 5 & 2 & 12 & - & 19 & $36 \%$ \\
\hline 1857 & 1540 & 59 & 34 & 12 & 40 & 145 & $10 \%$ \\
\hline Mortes & 31 & 1 & 2 & 9 & 3 & 15 & $49 \%$ \\
\hline 1858 & 1667 & 29 & 60 & 2 & 15 & 106 & $7 \%$ \\
\hline Mortes & 28 & 2 & 3 & 1 & 1 & 7 & $25 \%$ \\
\hline 1859 & 1841 & 22 & 24 & 7 & 15 & 68 & $4 \%$ \\
\hline Mortes & 31 & 1 & 3 & 4 & - & 8 & $26 \%$ \\
\hline 1860 & 1802 & 49 & 22 & 11 & 42 & 124 & $7 \%$ \\
\hline Mortes & 32 & 2 & 7 & 5 & - & 14 & $44 \%$ \\
\hline 1861 & $\left(2274^{\star}\right)$ & 19 & 58 & 17 & 206 & 300 & $14 \%$ \\
\hline Mortes & 36 & 1 & 2 & 6 & 5 & 14 & $39 \%$ \\
\hline
\end{tabular}




\begin{tabular}{|c|c|c|c|c|c|c|c|}
\hline \multicolumn{2}{|c|}{ Internações } & \multicolumn{6}{|c|}{ Doenças pulmonares } \\
\hline Ano & Internados & Bronquite & Pneumonia & Tuberculose & Outros & TOTAL & $\%$ \\
\hline 1862 & 2234 & 107 & 168 & 58 & 259 & 592 & $27 \%$ \\
\hline Mortes & 72 & 1 & 8 & 10 & 5 & 24 & $34 \%$ \\
\hline 1863 & 1998 & 60 & 107 & 44 & 56 & 267 & $14 \%$ \\
\hline Mortes & 54 & 1 & 4 & 13 & 1 & 19 & $36 \%$ \\
\hline 1864 & 2111 & 38 & 60 & 51 & 352 & 501 & $24 \%$ \\
\hline Mortes & 45 & - & 3 & 12 & 5 & 20 & $45 \%$ \\
\hline 1865 & 1750 & 25 & 33 & 22 & 201 & 281 & $16 \%$ \\
\hline Mortes & 64 & 4 & 4 & 12 & 3 & 23 & $36 \%$ \\
\hline 1866 & 2077 & 86 & 51 & 19 & 205 & 361 & $18 \%$ \\
\hline Mortes & 66 & 4 & 12 & 9 & - & 25 & $38 \%$ \\
\hline 1867 & 1781 & 91 & 33 & 12 & 84 & 220 & $13 \%$ \\
\hline Mortes & 30 & 3 & - & 4 & 1 & 8 & $27 \%$ \\
\hline 1868 & 1740 & 97 & 29 & 13 & 165 & 304 & $18 \%$ \\
\hline Mortes & 36 & 4 & 4 & 2 & 2 & 12 & $34 \%$ \\
\hline 1869 & 1777 & 158 & 20 & 4 & 138 & 320 & $18 \%$ \\
\hline Mortes & 34 & 3 & 1 & 3 & 1 & 8 & $24 \%$ \\
\hline 1870 & 1926 & 307 & 26 & 5 & 60 & 398 & $21 \%$ \\
\hline Mortes & 37 & 3 & 4 & 4 & - & 11 & $30 \%$ \\
\hline 1871 & 1983 & 295 & 6 & 2 & 95 & 398 & $20 \%$ \\
\hline Mortes & 32 & - & 3 & 1 & - & 4 & $13 \%$ \\
\hline 1872 & 1585 & 143 & 9 & 5 & 131 & 288 & $19 \%$ \\
\hline Mortes & 25 & 1 & - & 5 & 1 & 7 & $28 \%$ \\
\hline 1873 & 1093 & 116 & 13 & 1 & 95 & 225 & $21 \%$ \\
\hline Mortes & 27 & 3 & 1 & 1 & 2 & 7 & $26 \%$ \\
\hline 1874 & 1272 & 148 & 39 & 1 & 96 & 284 & $23 \%$ \\
\hline Mortes & 39 & 2 & 5 & - & - & 7 & $18 \%$ \\
\hline 1875 & 1562 & 241 & 25 & 5 & 128 & 399 & $26 \%$ \\
\hline Mortes & 35 & 6 & 5 & 5 & 1 & 17 & $49 \%$ \\
\hline 1876 & 1548 & 230 & 37 & 4 & $188^{*}$ & 459 & $30 \%$ \\
\hline Mortes & 32 & 1 & 4 & 3 & 2 & 10 & $32 \%$ \\
\hline 1877 & 1547 & 242 & 31 & 2 & 125 & 400 & $26 \%$ \\
\hline Mortes & 22 & 4 & 2 & 2 & 1 & 9 & $41 \%$ \\
\hline 1878 & 1460 & 208 & 29 & - & $182^{\star}$ & 419 & $29 \%$ \\
\hline Mortes & 22 & - & 5 & - & - & 5 & $23 \%$ \\
\hline
\end{tabular}




\begin{tabular}{c|c|c|c|c|c|c|c}
\hline \multicolumn{2}{c|}{ Internações } & \multicolumn{7}{c}{ Doenças pulmonares } \\
\hline Ano & Internados & Bronquite & Pneumonia & Tuberculose & Outros & TOTAL & $\%$ \\
\hline 1879 & 1360 & 206 & 14 & 1 & $180^{*}$ & 401 & $30 \%$ \\
\hline Mortes & 20 & 2 & 2 & 1 & 2 & 7 & $35 \%$ \\
\hline 1880 & 968 & 141 & 29 & 2 & 129 & 301 & $31 \%$ \\
\hline Mortes & 16 & - & 4 & 2 & 1 & 7 & $44 \%$ \\
\hline 1881 & 847 & 118 & 5 & 4 & 16 & 143 & $17 \%$ \\
\hline Mortes & 14 & 1 & 2 & 3 & - & 6 & $30 \%$ \\
\hline 1882 & 1040 & 207 & 7 & 1 & 97 & 312 & $30 \%$ \\
\hline Mortes & 15 & 1 & 1 & 1 & 1 & 4 & $27 \%$ \\
\hline 1883 & 894 & 208 & 4 & 2 & 72 & 286 & $32 \%$ \\
\hline Mortes & 13 & 1 & 1 & 2 & 1 & 5 & $39 \%$ \\
\hline 1884 & 894 & 163 & 2 & 5 & $\left(98^{\star}\right)$ & 268 & $30 \%$ \\
\hline Mortes & 13 & 2 & 1 & 1 & - & 4 & $31 \%$ \\
\hline Incidên- & 62157 & 4.406 & 1760 & 532 & 7.091 & 13.789 & $23 \%$ \\
\hline cia & 1470 & 81 & 162 & 140 & 127 & 510 & $35 \%$ \\
\hline Mortes & 1610 & & & &
\end{tabular}

*Houve incidência de epidemia.

Fonte: Annual report.

Tabela 2

Internados afetados por doenças que mais atacavam os escravos entre os pacientes do hospital da mina de Morro Velho

\begin{tabular}{c|c|c|c|c|c|c|c|c|c|c}
\hline \multicolumn{2}{c|}{ Internações } & \multicolumn{7}{|c|}{ Doenças que mais provocavam internações } & \\
\hline Ano & Internados & Acidentes & Boubas & Diarreia & Disenteria & Enterite & Reumatismo & Vermes & TOTAL & $\%$ \\
\hline 1847 & 1307 & 124 & - & 149 & 26 & 103 & 43 & 20 & 465 & $36 \%$ \\
\hline Mortes & 22 & 4 & - & 2 & 2 & 1 & - & - & 9 & $41 \%$ \\
\hline 1848 & 2335 & 547 & 4 & 307 & 28 & 133 & 98 & 46 & 1163 & $50 \%$ \\
\hline Mortes & 59 & 2 & 1 & 5 & 1 & - & - & - & 9 & $16 \%$ \\
\hline 1849 & 2333 & 538 & 7 & 302 & 32 & 171 & 77 & 20 & 1147 & $50 \%$ \\
\hline Mortes & 84 & - & - & 10 & 5 & - & - & 1 & 16 & $19 \%$ \\
\hline 1850 & 1386 & 217 & 9 & 249 & 57 & 42 & 48 & 5 & 627 & $46 \%$ \\
\hline Mortes & 52 & - & - & 10 & 9 & - & 1 & 1 & 21 & $41 \%$ \\
\hline 1851 & 1249 & 252 & 10 & 194 & 30 & 11 & 54 & 17 & 568 & $46 \%$ \\
\hline Mortes & 40 & 10 & - & 6 & 3 & - & - & - & 19 & $48 \%$ \\
\hline 1852 & 1580 & 302 & 10 & 179 & 39 & 107 & 121 & 12 & 770 & $49 \%$ \\
\hline Mortes & 43 & - & 1 & 5 & 7 & 1 & - & - & 14 & $33 \%$ \\
\hline
\end{tabular}




\begin{tabular}{|c|c|c|c|c|c|c|c|c|c|c|}
\hline \multicolumn{2}{|c|}{ Internações } & \multicolumn{8}{|c|}{ Doenças que mais provocavam internações } & \multirow[b]{2}{*}{$\%$} \\
\hline Ano & Internados & Acidentes & Boubas & Diarreia & Disenteria & Enterite & Reumatismo & Vermes & TOTAL & \\
\hline 1853 & 2370 & 488 & 10 & 478 & 53 & 116 & 151 & 5 & 1301 & $55 \%$ \\
\hline Mortes & 95 & - & - & 20 & 9 & - & - & - & 29 & $31 \%$ \\
\hline 1854 & 2178 & 574 & 18 & 245 & 20 & 274 & 135 & 15 & 1281 & $59 \%$ \\
\hline Mortes & 68 & - & - & 16 & 4 & - & - & - & 20 & $30 \%$ \\
\hline 1855 & 1839 & 509 & 13 & 91 & 14 & 466 & 130 & 21 & 1244 & $68 \%$ \\
\hline Mortes & 32 & - & - & 3 & 1 & - & - & - & 4 & $13 \%$ \\
\hline 1856 & 1813 & 484 & 22 & 34 & 9 & 396 & 77 & 29 & 1051 & $58 \%$ \\
\hline Mortes & 54 & - & - & - & 3 & - & - & - & 3 & $6 \%$ \\
\hline 1857 & 1540 & 610 & 12 & 54 & 6 & 516 & 52 & 27 & 1277 & $83 \%$ \\
\hline Mortes & 31 & 1 & - & 2 & 3 & - & - & - & 6 & $20 \%$ \\
\hline 1858 & 1667 & 484 & 9 & 133 & 1 & 453 & 66 & 30 & 1176 & $71 \%$ \\
\hline Mortes & 28 & & - & - & - & - & - & - & 0 & $0 \%$ \\
\hline 1859 & 1841 & 551 & 13 & 39 & - & 518 & 45 & 15 & 1181 & $65 \%$ \\
\hline Mortes & 31 & - & - & - & - & - & - & - & 0 & $0 \%$ \\
\hline 1860 & 1802 & 457 & 15 & 128 & 10 & 299 & 81 & 50 & 1040 & $58 \%$ \\
\hline Mortes & 32 & - & - & 1 & 3 & - & - & - & 4 & $13 \%$ \\
\hline 1861 & $\left(2274^{\star}\right)$ & 597 & 22 & 206 & 11 & 380 & 67 & 33 & 1316 & $58 \%$ \\
\hline Mortes & 36 & 3 & - & 3 & 3 & - & 1 & - & 10 & $28 \%$ \\
\hline 1862 & 2234 & 369 & 31 & 210 & 18 & 256 & 70 & 28 & 982 & $44 \%$ \\
\hline Mortes & 72 & 3 & - & 7 & 10 & - & - & 2 & 22 & $31 \%$ \\
\hline 1863 & 1998 & 360 & 34 & 114 & 12 & 377 & 120 & 16 & 1033 & $52 \%$ \\
\hline Mortes & 54 & - & - & 2 & 5 & - & - & - & 7 & $13 \%$ \\
\hline 1864 & 2111 & 357 & 54 & 158 & 28 & 335 & 106 & 56 & 1094 & $52 \%$ \\
\hline Mortes & 45 & 1 & - & 2 & 2 & - & - & - & 5 & $12 \%$ \\
\hline 1865 & 1750 & 379 & 52 & 134 & 85 & 296 & 86 & 25 & 1057 & $61 \%$ \\
\hline Mortes & 64 & 2 & - & 6 & 15 & - & 1 & - & 24 & $38 \%$ \\
\hline 1866 & 2077 & 450 & 45 & 83 & 24 & 383 & 128 & 47 & 1160 & $56 \%$ \\
\hline Mortes & 66 & 4 & - & 4 & - & 6 & - & 3 & 17 & $26 \%$ \\
\hline 1867 & 1781 & 376 & 44 & 44 & 6 & 347 & 199 & 53 & 1069 & $60 \%$ \\
\hline Mortes & 30 & - & - & 1 & 1 & 2 & 1 & - & 5 & $17 \%$ \\
\hline 1868 & 1740 & 272 & 74 & 40 & 19 & 366 & 117 & 56 & 944 & $55 \%$ \\
\hline Mortes & 36 & - & 1 & - & - & 1 & - & - & 2 & $6 \%$ \\
\hline 1869 & 1777 & 182 & 46 & 145 & 13 & 194 & 131 & 53 & 764 & $43 \%$ \\
\hline Mortes & 34 & - & - & - & 4 & - & - & - & 4 & $12 \%$ \\
\hline
\end{tabular}




\begin{tabular}{|c|c|c|c|c|c|c|c|c|c|c|}
\hline \multicolumn{2}{|c|}{ Internações } & \multicolumn{8}{|c|}{ Doenças que mais provocavam internações } & \multirow[b]{2}{*}{$\%$} \\
\hline Ano & Internados & Acidentes & Boubas & Diarreia & Disenteria & Enterite & Reumatismo & Vermes & TOTAL & \\
\hline 1870 & 1926 & 293 & 51 & 100 & 36 & 1 & 170 & 24 & 675 & $35 \%$ \\
\hline Mortes & 37 & 1 & - & 1 & 6 & - & - & - & 8 & $22 \%$ \\
\hline 1871 & 1983 & 339 & 26 & 155 & 50 & - & 148 & 56 & 774 & $39 \%$ \\
\hline Mortes & 32 & 1 & - & 2 & 5 & - & - & - & 8 & $25 \%$ \\
\hline 1872 & 1585 & 245 & 39 & 9 & 34 & - & 128 & 53 & 508 & $32 \%$ \\
\hline Mortes & 25 & 1 & - & - & 3 & - & - & - & 4 & $16 \%$ \\
\hline 1873 & 1093 & 192 & 26 & 61 & 13 & - & 55 & 20 & 367 & $34 \%$ \\
\hline Mortes & 27 & - & - & 4 & 4 & - & - & - & 8 & $30 \%$ \\
\hline 1874 & 1272 & 207 & 24 & 76 & 15 & - & 59 & 3 & 384 & $31 \%$ \\
\hline Mortes & 39 & 1 & - & 4 & 5 & - & - & - & 10 & $26 \%$ \\
\hline 1875 & 1562 & 261 & 13 & 65 & 12 & - & 79 & - & 430 & $28 \%$ \\
\hline Mortes & 35 & 1 & - & 1 & 1 & - & - & - & 3 & $9 \%$ \\
\hline 1876 & 1548 & 202 & 11 & 80 & 3 & - & 64 & - & 360 & $24 \%$ \\
\hline Mortes & 32 & 1 & - & 3 & - & - & - & - & 4 & $13 \%$ \\
\hline 1877 & 1547 & 281 & 16 & 100 & 6 & - & 86 & - & 489 & $32 \%$ \\
\hline Mortes & 22 & - & - & 1 & - & - & - & - & 1 & $5 \%$ \\
\hline 1878 & 1460 & 268 & 12 & 64 & - & - & 79 & - & 423 & $29 \%$ \\
\hline Mortes & 22 & 1 & - & 3 & - & - & - & - & 4 & $19 \%$ \\
\hline 1879 & 1360 & 212 & 14 & 48 & 4 & - & 72 & - & 350 & $26 \%$ \\
\hline Mortes & 20 & 1 & - & 1 & - & - & - & - & 2 & $10 \%$ \\
\hline 1880 & 968 & 152 & 12 & 33 & 4 & - & 69 & 1 & 271 & $28 \%$ \\
\hline Mortes & 16 & - & - & 2 & - & - & - & - & 2 & $13 \%$ \\
\hline 1881 & 847 & 180 & 5 & 72 & - & - & 48 & - & 305 & $36 \%$ \\
\hline Mortes & 14 & - & - & 3 & - & - & - & - & 3 & $8 \%$ \\
\hline 1882 & 1040 & 242 & 2 & 43 & - & - & 45 & - & 332 & $32 \%$ \\
\hline Mortes & 15 & - & - & 1 & - & - & - & - & 1 & $7 \%$ \\
\hline 1883 & 894 & 145 & 12 & 36 & - & - & 37 & - & 230 & $26 \%$ \\
\hline Mortes & 13 & - & - & - & - & - & - & - & 0 & 0 \\
\hline 1884 & 894 & 180 & 14 & 55 & 2 & 1 & 43 & - & 295 & $33 \%$ \\
\hline Mortes & 13 & - & - & - & 1 & 1 & - & - & 2 & $16 \%$ \\
\hline $\begin{array}{l}\text { Inter- } \\
\text { nados }\end{array}$ & 62157 & 12916 & 834 & 4844 & 835 & 6553 & 3388 & 843 & 30213 & $49 \%$ \\
\hline Mortes & 1470 & 37 & 3 & 131 & 115 & 13 & 4 & 5 & 427 & $29 \%$ \\
\hline
\end{tabular}

*Houve incidência de epidemia.

Fonte: Annual report. 
Tabela 3

Taxas de óbitos da população escrava de Morro Velho

\begin{tabular}{c|c|c|c|c|c|c|c}
\hline Ano & $\%$ & Ano & $\%$ & Ano & $\%$ & Ano & $\%$ \\
\hline 1841 & 6,1 & 1852 & 3,33 & 1863 & 4,62 & 1874 & 5,34 \\
\hline 1842 & 4,37 & 1853 & 6,15 & 1864 & 3,47 & 1875 & 5,55 \\
\hline 1843 & 5 & 1854 & 5,8 & 1865 & 5,22 & 1876 & 4,3 \\
\hline 1844 & 5,92 & 1855 & 2,84 & 1866 & 4,95 & 1877 & 3,69 \\
\hline 1845 & 4,78 & 1856 & 2,76 & 1867 & 3,86 & 1878 & 3,66 \\
\hline 1846 & 5,84 & 1857 & 5,03 & 1868 & 2,95 & 1879 & 4,18 \\
\hline 1847 & 2,5 & 1858 & 2,84 & 1869 & 3,09 & 1880 & 4,02 \\
\hline 1848 & 5,5 & 1859 & 2,9 & 1870 & 3,44 & 1881 & 3,98 \\
\hline 1849 & 7,26 & 1860 & 3,41 & 1871 & 3,23 & 1882 & 3,9 \\
\hline 1850 & 4,5 & 1861 & 3,08 & 1872 & 3,2 & 1883 & 3,77 \\
\hline 1851 & 3,33 & 1862 & 5,6 & 1873 & 3,6 & 1884 & 1,45 \\
\hline
\end{tabular}

Fonte: Annual report.

Tabela 4

Balanço demográfico das crianças escravas Crianças da companhia Crianças de escravos alugados

\begin{tabular}{c|c|c|c|c|c|c}
\hline Ano & Nascimento & Óbitos & Saldo & Nascimento & Óbitos & Saldo \\
\hline 1847 & 8 & 2 & 6 & 18 & 6 & 12 \\
\hline 1848 & 10 & 5 & 5 & 27 & 14 & 13 \\
\hline 1849 & - & 5 & - & 0 & 19 & - \\
\hline 1850 & 7 & - & - & 17 & 11 & 6 \\
\hline 1851 & 8 & 3 & 5 & 24 & 4 & 20 \\
\hline 1852 & 5 & - & - & 13 & 9 & 4 \\
\hline 1853 & 12 & 6 & 6 & 31 & 8 & 23 \\
\hline 1854 & 5 & 1 & 4 & 19 & 4 & 15 \\
\hline 1855 & 9 & 1 & 8 & 29 & 4 & 25 \\
\hline 1856 & 4 & 3 & 1 & 16 & 5 & 11 \\
\hline 1857 & 8 & 2 & 6 & 20 & 5 & 15 \\
\hline 1858 & 11 & 2 & 9 & 38 & 3 & 35 \\
\hline 1859 & 6 & 3 & 3 & 20 & 7 & 13 \\
\hline 1860 & 9 & 3 & 6 & 26 & 7 & 19 \\
\hline 1861 & 7 & 1 & 6 & 24 & 1 & 23 \\
\hline 1862 & 6 & 6 & 0 & 26 & 6 & 20 \\
\hline 1863 & 5 & 6 & -1 & 29 & 6 & 23 \\
\hline & & & & & & \\
\hline
\end{tabular}


Governo dos escravos na mina de Morro Velho

\begin{tabular}{c|c|c|c|c|c|c}
\hline Ano & Nascimento & Óbitos & Saldo & Nascimento & Óbitos & Saldo \\
\hline 1864 & 5 & 3 & 2 & 37 & 3 & 34 \\
\hline 1865 & 3 & 4 & -1 & 28 & 4 & 24 \\
\hline 1866 & 5 & 6 & -1 & 45 & 6 & 39 \\
\hline 1867 & 4 & 2 & 2 & 46 & 2 & 44 \\
\hline 1868 & 4 & 1 & 3 & 22 & 1 & 21 \\
\hline 1869 & 7 & - & - & 30 & - & - \\
\hline 1870 & 3 & - & - & 25 & - & - \\
\hline 1871 & 6 & - & - & 33 & - & - \\
\hline Total & 157 & 65 & 69 & 633 & 135 & 439 \\
\hline
\end{tabular}

Fonte: Annual report. Os quadros com sinal (-) significa que não foram encontrados dados.

Tabela 5

Balanço demográfico da população escrava em Morro Velho

\begin{tabular}{c|c|c|c|c|c|c}
\hline \multicolumn{3}{c|}{ Óbitos dos adultos } & \multicolumn{2}{c|}{$\begin{array}{c}\text { Nascimento das } \\
\text { crianças }\end{array}$} & \multicolumn{2}{c}{ Saldo } \\
\hline Ano & Cia & alugados & Cia & alugados & Cia & alugados \\
\hline 1848 & 8 & 45 & 5 & 18 & -3 & -27 \\
\hline 1849 & 16 & 65 & - & - & - & - \\
\hline 1850 & 8 & 50 & - & 6 & - & -44 \\
\hline 1851 & 4 & 35 & 5 & 25 & 1 & -10 \\
\hline 1852 & 6 & 34 & - & 4 & - & -30 \\
\hline 1853 & 8 & 87 & 6 & 29 & -2 & -58 \\
\hline 1854 & 7 & 64 & 4 & 19 & -3 & -45 \\
\hline 1855 & 3 & 4 & 8 & 33 & 5 & 29 \\
\hline 1856 & 6 & 49 & 1 & 12 & -5 & -37 \\
\hline 1857 & 5 & 21 & 6 & 21 & 1 & 0 \\
\hline 1858 & 7 & 25 & 9 & 44 & 2 & 19 \\
\hline 1859 & 6 & 24 & 3 & 16 & -3 & -8 \\
\hline 1860 & 9 & 33 & 6 & 25 & -3 & -8 \\
\hline 1861 & 5 & 43 & 6 & 29 & 1 & -14 \\
\hline 1862 & 5 & 72 & - & - & - & - \\
\hline 1863 & 15 & 63 & 1 & 22 & -14 & -41 \\
\hline 1864 & 5 & 47 & 2 & 36 & -3 & -11 \\
\hline 1865 & 4 & 65 & 1 & 23 & -3 & -42 \\
\hline 1866 & 11 & 64 & 1 & 38 & -10 & -26 \\
\hline 1867 & 6 & 54 & 2 & 46 & -4 & -8 \\
\hline 1868 & 7 & 38 & 3 & 24 & -4 & -14 \\
\hline Total & 151 & 1027 & 68 & 470 & -48 & -375 \\
\hline
\end{tabular}

Fonte: Annual report. Os quadros com sinal (-) significa que não foram encontrados dados. 


\section{Gráfico 1}

Evolução da população escrava da mina de Morro Velho

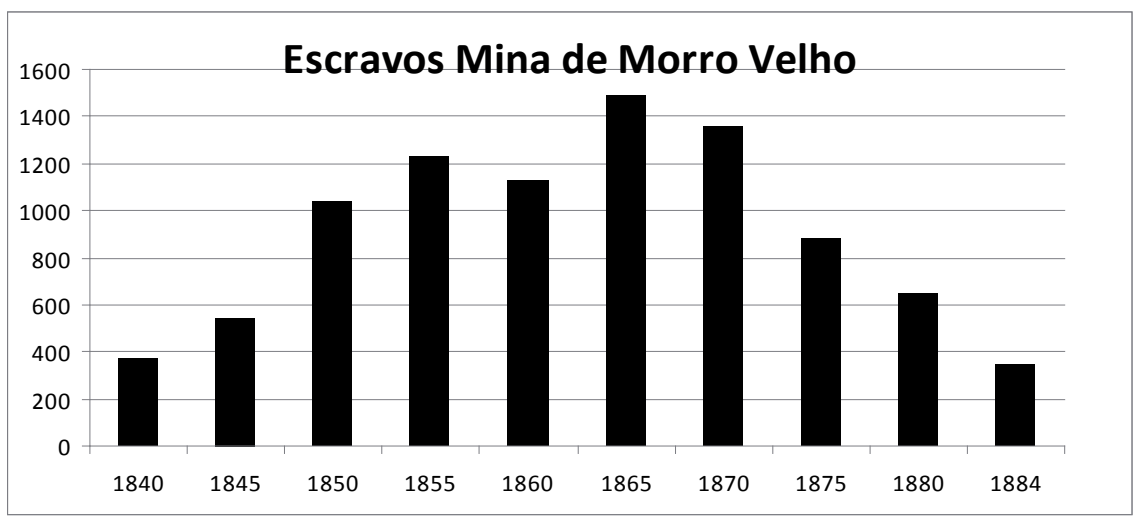

Este gráfico foi feito com base na tabela elaborada por LIBBY, Douglas Cole. Trabalho escravo na mina de Morro Velho, p.167.

\section{Gráfico 2}

Balanço das taxas de óbitos da população escrava de Morro Velho

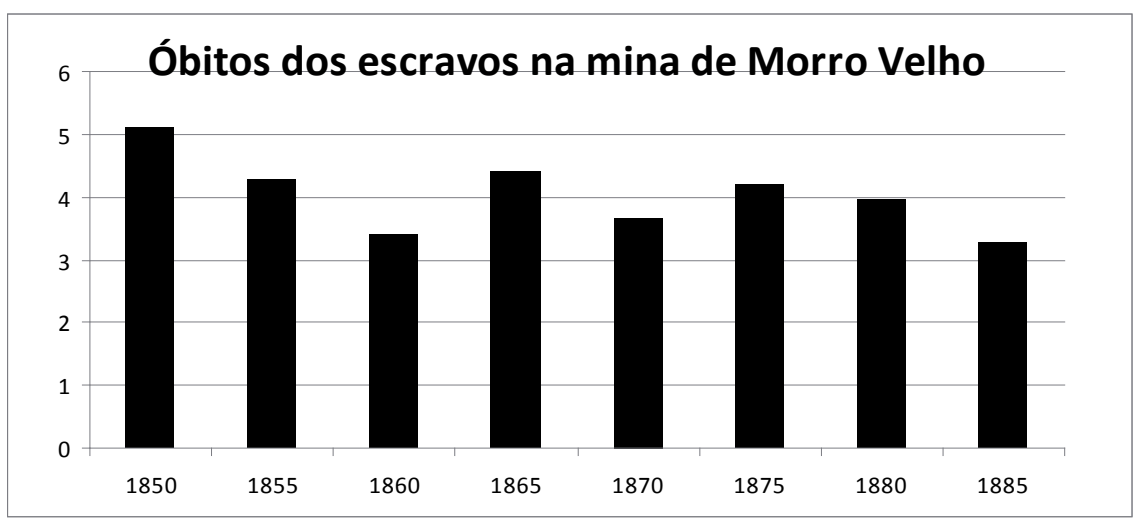

Elaborado com base na Tabela 3. 


\section{Gráfico 3}

Balanço do nascimento de escravos na mina de Morro Velho

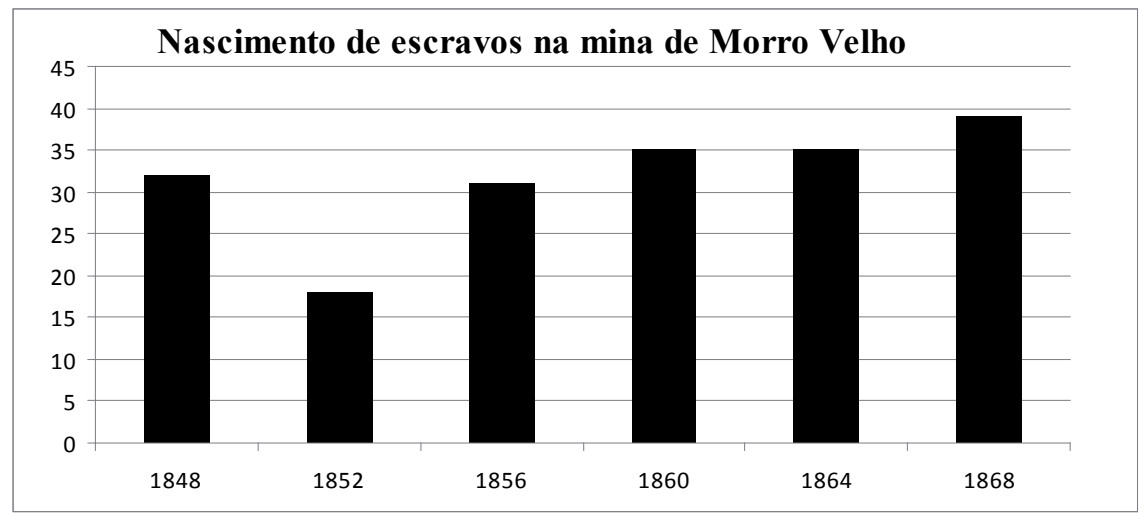

Elaborado com base na tabela 4.

Gráfico 4

Balanço dos óbitos de crianças escravas na mina de Morro Velho

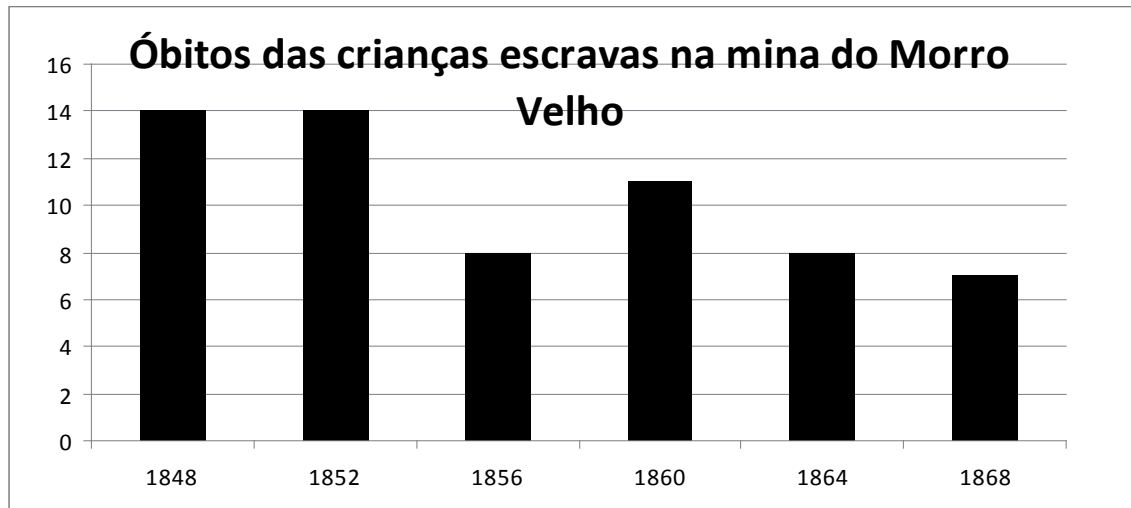

Elaborado com base na Tabela 4. 


\section{Gráfico 5}

Saldo dos sobreviventes entre as crianças escravas

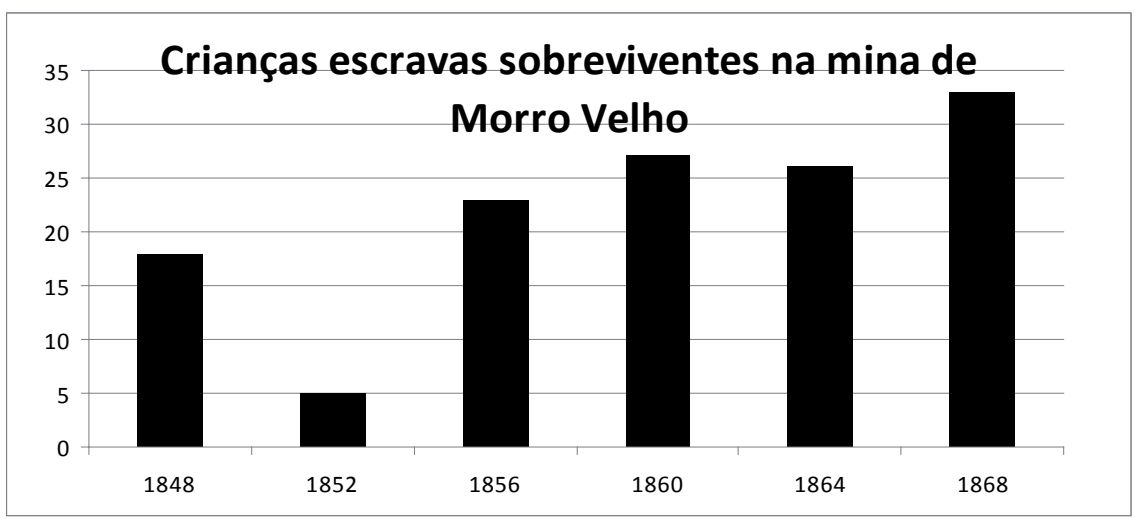

Elaborado com base na Tabela 4. 